DOI: $10.20472 / T E .2015 .3 .4 .001$

\title{
MEASURING LEADERSHIP ATTRIBUTES IN VOCATIONAL AND TECHNICAL EDUCATION: THE COLLEGE OF TECHNOLOGICAL STUDIES, KUWAIT, AS A CASE STUDY.
}

\author{
SALAH AL-ALI
}

\begin{abstract}
:
Due to the rapid change in science and technology in world economy, the issue of forging vocational and technical colleges is considered significant, especially in developing countries (e.g. Kuwait), where the shortage of semi-skilled indigenous manpower is highly noted in various sectors of the economy. The success of vocational and technical education would depend, to great extend, on those who run such institutions. The distinction between managing an academic institution and vocational and technical education institution has to be clearly made so that tangible outcomes can be achieved. The fact is that vocational and technical education has its own unique characteristics that have to be thoroughly absorbed by those who are intending to run such institutions. The study would be based on extensive fieldwork that encompassed a review of related literature, personal interviews with selected heads of departments and the head of Industrial Training Programs. The objectives are to measure leadership attributes (e.g. setting an appropriate strategy and plan, encouraging team work, vision, communication skills, confidence, and persistence). Finally, the paper would argues that unless the management of the College of technological Studies, CTS, realises the importance of the application of leadership attributes, the CTS would not be able to supply local industries with the needed manpower. Thus, increasing dependence on expatriates for years to come.
\end{abstract}

\section{Keywords:}

Key words: Vocational and technical Education, developing Indigenous Manpower, Interaction between vocational and technical education and local industries, Kuwait.

JEL Classification: A22

\section{Authors:}

SALAH AL-ALI, College of technological Studies, Kuwait, Email: drsalali@yahoo.com

\section{Citation:}

SALAH AL-ALI (2015). Measuring Leadership Attributes in Vocational and Technical Education: The College of Technological Studies, Kuwait, As A Case Study.. International Journal of Teaching and Education, Vol. III(4), pp. 1-5., 10.20472/TE.2015.3.4.001 


\section{Introduction:}

The effectiveness and efficiency of vocational education and training programmes has long been a national concern for many developing countries, particularly in the Gulf region, where a shortage of skilled and semi-skilled national manpower constitutes the main problem in many sectors of the economy (e.g. Kuwait, United Arab Emirates, Saudi Arabia). In the Gulf States, expatriates form $58 \%$ of the total workforce. In the United Arab Emirates and Qatar, expatriates form 87\% of the total workforce, followed by Kuwait at $69 \%$, and Bahrain at $49 \%$. Saudi Arabia and Oman are the only countries in the Gulf States with a clear majority of national labour, with nationals representing $73 \%$ and $70 \%$ of the total workforce, respectively (Centre for Middle East Commercial Information, 2011). Leo Maglen (1997) defines Vocational Education and Training (VET), as: “...taken to encompass all educational and instructional experiences - be they formal or informal, pre-employment or employment related, off-the-job - that are designed to directly enhance the skills, knowledge, competencies and capabilities of individuals, required in undertaking gainful employment". (Maglen in Blunden, 1997). John Stevenson (1990) has argued that course design in VET is based on three principles. These are relevance, responsiveness, and uniqueness. In his view, VET courses are relevant in the sense that they fulfil the requirements identified by employers. In terms of responsiveness, VET courses address the knowledge and skills required by the marketplace, and the application of these two principles enables VET courses to provide appropriate and useful training. In the $21^{\text {st }}$ century, workers require skills such as decision making, solving real work problems, time management, risk-taking and communication skills in order to be accepted to work in industries. (Robinson, Garton, \& Vaughn, 2007). Students in vocational and technical education colleges need to incorporate knowledge, skills and positive attitude (Baartman and De Bruijn 2011), while they present need to enhance a recognised identity. Students need to know about organizational structure, labour market required knowledge, skills and attitudes, job seeking and job keeping skills. They also need to understand how to acquire and use information, enhance their skills, solve actal work problems, and manage and adapt technology mostly used in related industry.

In Kuwait, the Public Authority for Applied Education and Training (PAAE\&T) has been established to respond to the urgent need for skilled and semi-skilled national labour. The PAAE\&T consists of the College of Technological Studies, the College of Business Studies, the College of Business Education, the College of Health Service, the High Institute of Energy, the Sabah Al-Salem and Shweekh branches of the Industrial Training Institute, the Institute of Nursing, and the Higher Institute for Communications and Navigation. Special efforts were made to identify those factors that significantly shape students' knowledge, skills and attitudes and to measure employer's perceptions of the standard of PAAE\&T graduates. This research was conducted to assist decision makers in developing an appropriate strategy, ensuring the capability of indigenous labour to deal with imported technology, and reducing or removing dependence on expatriates. 


\section{Research objectives}

a. Measuring the awareness of the heads of departments' of the overall college strategy and plan.

b. Identifying and examining the types of leadership's course completed by the selected heads of departments.

c. Identifying and examining the type of departmental plan in upgrading the standard of graduates.

d. Identifying and examining the type of methods (if any) applied in determining Industrial manpower requirements.

e. Summary and conclusions.

\section{Research methodology}

Three departments at the CTS were selected for the purpose of this research. They are namely, electronic Engineering Department, the Electrical Engineering Department, and the Petroleum Engineering Department. The selection criterion for the three departments was to select those departments which have direct role in supporting the country's economy (e.g. oil industry and electricity and power industry). Several issues were investigated and discussed with the selected heads of departments. Among which were, whether the heads of departments have enrolled in

training courses related to leaderships skills, participated in setting overall college strategy and plan, have set a departmental plan to enhance the level of their graduates, adapted a proper method in determining industrial manpower needs, and whether they have set an efficient scheme to evaluated graduates efficiency at workplace. A personal in-depth interview was also conducted with the head of the industrial liaison office. Among the issues discussed were: whether the head of the industrial liaison office has participated in setting the overall college strategy and plan, participated in determining industrial needs, and applied a proper evaluation scheme for graduates.

\section{Research findings}

\subsection{Measuring the heads of departments awareness of the CTS Strategies \& Objectives.}

The issue of staff awareness of the overall organisation objectives and strategies is one of management's priorities. It is though that through a proper understanding of such objectives, staff can dedicate their efforts and use the available organisational resources in a way which will serve the overall organisational objectives. In this study, 
an attempt was made to measure the heads of department awareness of the CTS strategies and objectives. The findings indicated that all selected heads of departments are well aware of their college strategy and objectives. However, the selected heads of departments have not participated in the setting or reviewing the overall college plan. They also indicated that they are unaware of the evaluation methods (if any) applied by the management in ensuring that objectives have been achieved and graduates have met industrial requirements. The industrial liaison office stated that he is well aware of the overall college strategy and plan. However, he is not sure whether the embodied objectives in the plan are successfully achieved.

\subsection{Identifying and examining the types of leadership's course completed by the selected heads of departments.}

The study revealed that no specific leadership's courses have been assigned for the selected heads of departments. A committee formed by the Dean of the College of technological Studies to interview candidates for the heads of department's positions. Several criteria's were considered. Among which: years of working experience in the college, number of papers published in either referred journals or conferences, participating in social development activities, and specific management skills (e.g. future vision to improve the standard of the college, communication skills, planning skills). Even after the selection of the heads of departments, no specific leadership's courses have been set to enhance their knowledge, skills and attitudes.

\subsection{Identifying and examining the type of departmental plan in upgrading the standard of graduates.}

Indeed all selected heads of department are eager to improve the standard of their graduates. However, no clear, specific, and agreeable plan was identified in enhancing the quality of graduates. It is totally left to each department to take the necessary measures to improve the quality of their graduates. It is worth mentioning at this point that, no quality assurance system is applied in the selected departments. Several aspects may include in such system such as: curriculum review and development, improving the standard of learning in workshops and laboratories, enhancing research and developments skills, and strengthening the quality of link with related industry.

\subsection{Identifying and examining the type of methods (if any) applied in determining Industrial manpower requirements.}

Selected heads of departments were unsure of the right number needed by related industry from graduates. In other words, there is no sign of any updated data on the expected number of graduates or their specialisation, which is required by industry. This unpleasant situation would not help the heads of departments in setting, to some 
extent, an accurate departmental plan for meeting future manpower requirements. The Head of Industrial Training Programmes stressed the need to know the future requirements of industry from the selected department's graduates in specific and the College of technological Studies in general.

\section{Summary and Conclusions}

Vocational and technical education has unique characteristics. It is completely different from normal academic education. Therefore, there are specific skills have to be marinated by those who are attending to manage such institution. Leadership skills are considered significant in order to achieve the setting objectives. The differentiation between managing and leading vocational education has to be discussed extensively by key figure in the education sector in Kuwait. Since the country is aiming to reduce dependence on expatriates. Leadership's skills such are setting proper strategy and planning for the future of manpower in Kuwait must be one on first priority of those who tackle the issue of building indigenous capability. The findings of this research showed that the selected heads of department slack some skills related to leadership and thus face with barriers in responding to the actual needs of industry. As a results, industry seems reluctant to employ graduates from vocational education institutions since they lack the necessary knowledge, skills and attitudes required by industry.

\section{References:}

Baartman, L. K. J., \& De Bruijn, E. (2011). Integrating knowledge, skills and attitudes: Conceptualizing learning processes towards vocational competence. Educational Research Review, 6, 125-134.

Centre for Middle East Commercial Information, AME, Friday 29 July,

2011, Main Page.

Maglen L., Introduction, in Blunden R, (ed), (1997) Teaching and learning in Vocational Education and Training, Social Sciences Press, Katoomba.

National Board for Professional Teaching Standards (1999) Guide to national certification. Washington, DC: Author.

Stevenson J, (1990) Curriculum and Teaching on TAFE, in Stevenson J, (1994), A Collection of Conference Papers Presented by John Stevenson, Centre for Skill Formation Research, Griffith University, pp.11-28. 